\title{
Impact of pretreatment serum cholinesterase level in unresectable advanced hepatocellular carcinoma patients treated with sorafenib
}

\author{
HARUHIKO TAKEDA, HIROKI NISHIKAWA, ERIKO IGUCHI, YOSHIAKI OHARA, AZUSA SAKAMOTO, \\ KEIICHI HATAMARU, SHINICHIRO HENMI, SUMIO SAITO, AKIHIRO NASU, HIDEYUKI KOMEKADO, \\ RYUICHI KITA, TORU KIMURA and YUKIO OSAKI
}

Department of Gastroenterology and Hepatology, Osaka Red Cross Hospital, Osaka, Japan

Received July 5, 2012; Accepted November 16, 2012

DOI: $10.3892 / \mathrm{mco} .2012 .48$

\begin{abstract}
The value of serum cholinesterase (ChE) level as a predictive marker in sorafenib therapy for advanced hepatocellular carcinoma (HCC) has not yet been investigated. The present retrospective study therefore analyzed the impact of the serum ChE level in 93 patients with advanced HCC treated with sorafenib. Patients were categorized into two groups: group A with pretreatment serum $\mathrm{ChE} \geq 140 \mathrm{IU} / 1(\mathrm{n}=46)$ and group B with pretreatment serum $\mathrm{ChE}<140 \mathrm{IU} / \mathrm{l}(\mathrm{n}=47)$. The correlation between clinicopathological findings, including serum ChE level, and overall survival (OS) and liver damage during sorafenib therapy was investigated. The median OS of the patients was 275 days, while OS was markedly higher in group A compared to group B ( $\mathrm{P}=0.002)$. In 70 Child-Pugh A patients, serum ChE level was a significant prognostic predictor in multivariate analysis $[\mathrm{P}=0.019$, hazard ratio $(\mathrm{HR})$ $=2.612 ; 95 \%$ confidence interval $(\mathrm{CI}), 1.174-5.810]$. During sorafenib treatment, 22 patients developed liver dysfunction of grade 3 or higher. Only two group A patients (4.3\%) developed liver dysfunction, compared to 20 group B patients $(42.6 \%)(\mathrm{P}<0.001)$. Multivariate analysis demonstrated that the pretreatment serum $\mathrm{ChE}$ level was the strongest predictor of liver damage ( $\mathrm{P}=0.002, \mathrm{HR}=0.061,95 \%$ CI: $0.010-0.373$ ), indicating serum $\mathrm{ChE}<140 \mathrm{IU} / 1$ to be the only independent predictor associated with severe liver function damage during sorafenib treatment in 70 patients with grade A Child-Pugh ( $\mathrm{P}=0.016$; HR $=0.122 ; 95 \% \mathrm{CI}, 0.022-0.676)$. In conclusion, lower serum $\mathrm{ChE}$ level is a significant predictor of poor prognosis and severe liver damage in HCC patients treated with sorafenib. Advanced HCC patients with lower serum ChE
\end{abstract}

Correspondence to: Dr Haruhiko Takeda, Department of Gastroenterology and Hepatology, Osaka Red Cross Hospital, 5-30 Fudegasaki-cho, Tennoji-ku, Osaka 543-8555, Japan

E-mail: htakeda511@yahoo.co.jp

Key words: cholinesterase, sorafenib, hepatocellular carcinoma, prognostic factor, liver dysfunction levels, including those with a Child-Pugh A pretreatment liver function score, should be given sorafenib therapy with caution.

\section{Introduction}

Hepatocellular carcinoma (HCC) is generally considered to be chemoresistant, and the results of systemic chemotherapy have been unsatisfactory (1). Sorafenib (Nexavar, Bayer Healthcare Pharmaceuticals, Pittsburgh, PA, USA) is a multi-kinase inhibitor that blocks tumor growth and cell proliferation, and was the first systemic chemotherapeutic agent found to improve the survival time of patients with advanced HCC, in the SHARP as well as Asia-Pacific trials (2-5). However, findings of these trials showed that several patients with advanced HCC remained refractory to sorafenib, and the factors determining the patients benefiting from sorafenib therapy remain unclear (2-5).

Although several studies have investigated the prognostic factors in sorafenib treatment, no consensus factors have yet been identified (6-12). Pretreatment liver function parameters, such as Child-Pugh classification, serum bilirubin, serum albumin (ALB) and serum aminotransferase have been reported as prognostic factors in sorafenib treatment (6-12).

Serum cholinesterase (ChE) in combination with ALB is one of the main indices of the protein-synthetic ability of the liver (13-19). Unlike ALB level, which is influenced by various factors such as bleeding, inflammation, chronic renal diseases or branched chain amino acid administration, the serum ChE level simply reflects the background liver function (13-19). Serum ChE level has been reported to be an important prognostic factor in malignancies other than $\mathrm{HCC}$, including gastric and pancreatic cancers treated with systemic chemotherapy (13-17). In addition, serum ChE level has been reported as a prognostic factor in cholangiocellular carcinoma patients treated with radiotherapy (18), patients with recurrent HCC after hepatectomy (20), and in liver transplantation recipients with chronic end-stage liver disease (21). Serum ChE thus seems to be significantly involved in the treatment of several malignancies $(22,23)$. However, to the best of our knowledge, no studies have yet investigated the value of serum $\mathrm{ChE}$ level as a predictive marker in sorafenib 
therapy for advanced HCC. In the present study, we therefore focused on serum ChE level as an index of liver function and investigated its significance in advanced HCC patients treated with sorafenib.

\section{Patients and methods}

Patients. A total of 102 patients with unresectable HCC were treated with sorafenib at the Department of Gastroenterology and Hepatology (Osaka Red Cross Hospital, Osaka, Japan) between June, 2009 and February 2012. The indications for sorafenib therapy were: unresectable advanced HCC determined by dynamic computed tomography (CT) scan; Eastern Cooperative Oncology Group (ECOG) performance status of 0-2; pretreatment Child-Pugh classification of A or B; presence of extrahepatic metastases; refractory to previous HCC therapies, such as transcatheter arterial chemoembolization (TACE); unsuitability for TACE for anatomical reasons and absence of uncontrollable ascites. Pretreatment serum $\mathrm{ChE}$ levels were not measured in nine $(8.8 \%)$ of the 102 patients, and the present study population therefore consisted of 93 patients with measured pretreatment serum ChE levels.

Study protocol. The median pretreatment serum ChE level was 138 IU/l (range, 31-276 IU/l). Patients were therefore categorized into two groups: group A with a pretreatment serum $\mathrm{ChE}$ level $\geq 140 \mathrm{IU} / \mathrm{l}(\mathrm{n}=46)$ and group B with a pretreatment serum ChE level <140 IU/l $(n=47)$. We retrospectively analyzed the correlation between overall survival (OS), and pretreatment serum ChE level as well as other pretreatment clinicopathological variables including age, gender, cause of liver disease, Child-Pugh classification, pretreatment tumor characteristics such as tumor node metastasis (TNM) stage, Barcelona Clinic Liver Cancer (BCLC) stage, portal vein tumor invasion and metastatic sites, tumor markers, laboratory data such as total bilirubin (TBIL), ALB, aspartate aminotransferase (AST), alanine aminotransferase (ALT), prothrombin time and serum creatinine, as well as the presence of ascites. We also examined the correlation between the development of severe liver damage during sorafenib therapy, and pretreatment $\mathrm{ChE}$ level and the above-mentioned clinicopathological variables. Severe liver damage was defined as: liver dysfunction occurring within 3 months from the administration of sorafenib, including elevated AST, ALT and TBIL, and hepatic encephalopathy or liver failure of grade 3 or higher based on the Common Terminology Criteria for Adverse Events (CTCAE) version 4.0. In addition, we performed subgroup analyses on patients with good liver function defined as Child-Pugh class A. Written informed consent was obtained from the patients prior to sorafenib therapy. This retrospective study protocol was in compliance with the provisions of the Declaration of Helsinki.

Initial sorafenib dose and treatment discontinuation. The initial sorafenib dose was determined according to factors, such as patient body weight, body surface area, age, comorbid diseases, performance status and liver function. The initial sorafenib dose in this study ranged from 400 to $800 \mathrm{mg} /$ day. This took into account the fact that studies in several countries, including Japan, have reported serious adverse events in several advanced HCC patients administered an initial

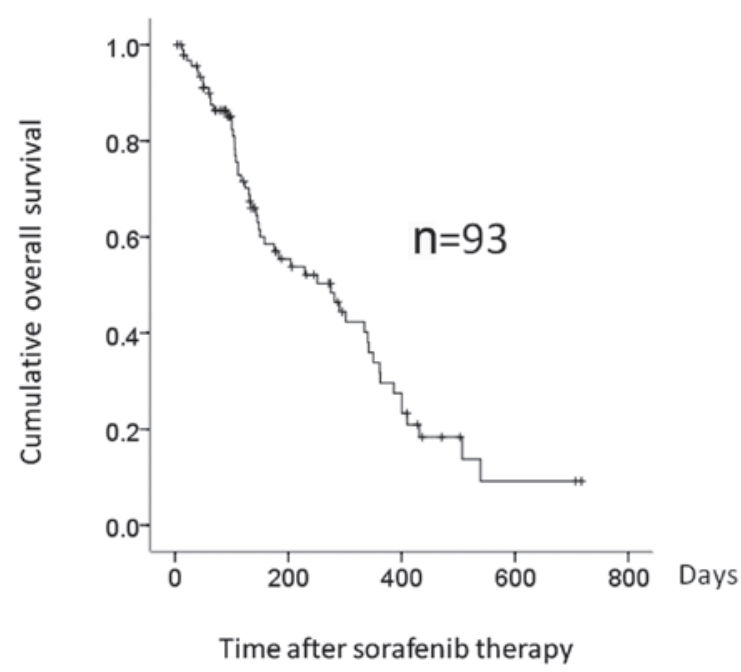

Figure 1. Cumulative overall survival $(\mathrm{OS})$ for all the cases $(\mathrm{n}=93)$. The median OS was 275 days.

sorafenib dose of $800 \mathrm{mg} /$ day, leading to treatment discontinuation. The initial sorafenib dose was therefore determined taking this fact into consideration. Sorafenib treatment was continued until disease progression, unacceptable drug-related toxicity or the patient's decision to discontinue.

Statistical analysis. OS curves were generated using the Kaplan-Meier method and compared using log-rank tests. OS was calculated from the initial date of sorafenib treatment until death by any cause or until the last follow-up. Serum $\mathrm{ChE}$ level and other clinicopathological variables were analyzed using univariate and multivariate analyses. Regarding OS, the Cox proportional hazard model was used for multivariate analysis of factors considered significant in univariate analysis. Associations between pretreatment serum ChE level and additional clinicopathological variables, and the development of liver damage during sorafenib treatment were also examined using Fisher's exact tests. Regarding the development of liver damage, the variables found to be significant in the univariate analysis were subjected to the multivariate analysis using logistic regression analysis. Data were presented as the median value (range). $\mathrm{P}<0.05$ was considered to indicate a statistically significant difference. Statistical analyses were carried out using the SPSS software (SPSS for Windows 15.0, SPSS, Inc., Chicago, IL, USA).

\section{Results}

Patient characteristics. The baseline characteristics of the two groups are shown in Table I. Group A comprised 37 males and 9 females, with a median age of 70 years (range, 46-86). Group B comprised 35 males and 12 females, with a median age of 71 years (range, 47-89). With regard to tumor characteristics, 22 patients in group A and 19 patients in group B had extrahepatic metastases, while 29 and 27 patients were classified with BCLC stage C disease in groups A and B, respectively. Most patients had received previous therapies for HCC: one or more sessions of TACE had been performed in 75 patients, radiofrequency ablation or percutaneous ethanol 
Table I. Baseline characteristics of patients with advanced hepatocellular carcinoma.

\begin{tabular}{|c|c|c|c|}
\hline Variable & $\begin{array}{c}\text { Group } A(n=46) \\
N \text { or median value (range) }\end{array}$ & $\begin{array}{c}\text { Group } B(n=47) \\
N \text { or median value (range) }\end{array}$ & P-value \\
\hline Age (years) & $70(46-86)$ & $71(47-89)$ & $0.779^{\mathrm{a}}$ \\
\hline Gender (male/female) & $37 / 9$ & $35 / 12$ & $0.794^{\mathrm{b}}$ \\
\hline Body surface area $\left(\mathrm{m}^{2}\right)$ & $1.59(1.09-2.18)$ & $1.58(1.38-1.89)$ & $0.852^{\mathrm{a}}$ \\
\hline \multicolumn{4}{|l|}{ Etiology of liver disease } \\
\hline Hepatitis B/hepatitis C/non-B non-C & $10 / 24 / 12$ & $7 / 32 / 8$ & $0.341^{\mathrm{b}}$ \\
\hline \multicolumn{4}{|l|}{ TNM stage } \\
\hline Stage II/III/IVA/IVB & $3 / 14 / 7 / 22$ & $1 / 18 / 9 / 19$ & $0.822^{\mathrm{b}}$ \\
\hline \multicolumn{4}{|l|}{ Site of metastases (yes/no) } \\
\hline Lung & $13 / 33$ & $7 / 40$ & $0.136^{\mathrm{b}}$ \\
\hline Bone & $8 / 38$ & $8 / 39$ & $1.000^{\mathrm{b}}$ \\
\hline Adrenal & $1 / 45$ & $2 / 45$ & $1.000^{\mathrm{b}}$ \\
\hline Lymph node & $11 / 35$ & $9 / 38$ & $0.621^{\mathrm{b}}$ \\
\hline Portal vein tumor invasion (yes/no) & $8 / 38$ & $10 / 37$ & $0.794^{\mathrm{b}}$ \\
\hline ECOG PS, $0 / 1 / 2$ & $40 / 5 / 1$ & $40 / 4 / 3$ & $0.802^{\mathrm{b}}$ \\
\hline Child-Pugh classification, A/B & $41 / 5$ & $29 / 18$ & $0.003^{\mathrm{b}}$ \\
\hline BCLC stage, $\mathrm{B} / \mathrm{C}$ & $17 / 29$ & $20 / 27$ & $0.673^{\mathrm{b}}$ \\
\hline Pretreatment serum AFP (ng/ml) & $476(2.2-270,300)$ & $98(2.9-688,400)$ & $0.251^{\mathrm{a}}$ \\
\hline Pretreatment serum DCP (mAU/ml) & $1935(10-98,510)$ & $937(11-421,210)$ & $0.462^{\mathrm{a}}$ \\
\hline \multicolumn{4}{|l|}{ Previous therapies for HCC (yes/no) } \\
\hline TACE & $40 / 6$ & $35 / 12$ & $0.322^{\mathrm{b}}$ \\
\hline RFA or PEIT & $15 / 31$ & $12 / 35$ & $0.649^{\mathrm{b}}$ \\
\hline Surgery & $9 / 37$ & $6 / 41$ & $0.106^{\mathrm{b}}$ \\
\hline Radiation & $5 / 41$ & $11 / 36$ & $0.089^{\mathrm{b}}$ \\
\hline Initial sorafenib dose ( $800 / 400 \mathrm{mg}$ per day) & $13 / 33$ & $13 / 34$ & $1.000^{\mathrm{b}}$ \\
\hline \multicolumn{4}{|l|}{ Treatment response } \\
\hline $\mathrm{CR} / \mathrm{PR} / \mathrm{SD} / \mathrm{PD} / \mathrm{NE}$ & $0 / 9 / 9 / 14 / 14$ & $1 / 2 / 11 / 10 / 23$ & $0.410^{\mathrm{b}}$ \\
\hline
\end{tabular}

${ }^{a}$ Unpaired t-test; ${ }^{b}$ Fisher's exact test; N, number; TNM, tumor node metastasis; ECOG PS, Eastern Cooperative Oncology Group Performance Status; BCLC, Barcelona Clinic Liver Cancer; AFP, $\alpha$-fetoprotein; DCP, des- $\gamma$-carboxy prothrombin; HCC, hepatocellular carcinoma; TACE, transcatheter arterial chemoembolization; RFA, radiofrequency thermal ablation; PEIT, percutaneous ethanol injection therapy; $\mathrm{CR}$, complete response; PR, partial response; SD, stable disease; PD, progressive disease; NE, not evaluated.

injection therapy in 27 , hepatectomy in 15 and palliative radiation therapy in 16 patients. With regard to pretreatment liver function, 73 patients $(78.5 \%)$ had Child-Pugh $\mathrm{A}$ and $20(21.5 \%)$ had Child-Pugh B function. The incidence of patients with Child-Pugh A status was significantly higher in group A compared to group $\mathrm{B}(\mathrm{P}=0.003)$.

Sorafenib was initiated at $800 \mathrm{mg} /$ day in 26 patients $(28.0 \%)$ and at $400 \mathrm{mg} /$ day in 67 patients $(72.0 \%)$. With regard to treatment response, complete response was obtained in 1 patient, partial response (PR) in 10 patients, stable disease in 26 and progressive disease in 25 patients, based on the modified Response Evaluation Criteria in Solid Tumor (mRECIST) (24).

Predictive factors for $O S$ and causes of mortality. The median observation period for the analyzed cases was 136 days (range, 3-716), while the median OS was 275 days (Fig. 1). Fifty-three patients $(57.0 \%)$ succumbed to the disease during the observation period. The causes of mortlity were HCC progression in 44 patients, liver failure in 3 and miscellaneous causes in 6 patients. The median OS was 319 and 106 days for group A and $\mathrm{B}$ patients, respectively ( $\mathrm{P}=0.002)$ (Fig. 2).

Univariate analysis revealed the presence of bone metastases $(\mathrm{P}=0.005)$, ALB level $\geq 3.5 \mathrm{~g} / \mathrm{dl}(\mathrm{P}=0.042)$, serum ChE level $\geq 140$ IU/1 $(\mathrm{P}=0.002)$ and the presence of ascites $(\mathrm{P}=0.001)$ to be significant independent factors linked to OS (Table II). However, multivariate analyses of the four factors found to be significant by univariate analysis revealed only bone metastases $(\mathrm{P}=0.018)$ and the presence of ascites $(\mathrm{P}=0.011)$ to be significant independent factors linked to OS (Table II). Serum ChE level tended to correlate with OS, though the correlation was not significant in multivariate analysis $(\mathrm{P}=0.068)$ (Table II). 
Table II. Univariate and multivariate analyses of factors contributing to overall survival in the cases $(n=93)$.

\begin{tabular}{|c|c|c|c|c|c|}
\hline \multirow[b]{2}{*}{ Variable } & \multirow[b]{2}{*}{$\mathrm{N}$} & \multirow{2}{*}{$\frac{\text { Univariate analysis }_{\mathrm{P}-\text { value }^{\mathrm{a}}}}{\mathrm{P}}$} & \multicolumn{3}{|c|}{ Multivariate analysis } \\
\hline & & & HR & $95 \% \mathrm{CI}$ & P-value ${ }^{b}$ \\
\hline Age $\geq 70$ years (yes/no) & $43 / 50$ & 0.960 & & & \\
\hline Gender (male/female) & $76 / 17$ & 0.308 & & & \\
\hline HBsAg-positive (yes/no) & $17 / 76$ & 0.446 & & & \\
\hline Child-Pugh classification, A/B & $70 / 23$ & 0.099 & & & \\
\hline TNM stage, stage III/stage IVA or IVB & $37 / 56$ & 0.149 & & & \\
\hline BCLC stage, $\mathrm{B} / \mathrm{C}$ & $37 / 56$ & 0.375 & & & \\
\hline Portal vein tumor invasion (yes/no) & $18 / 75$ & 0.377 & & & \\
\hline Bone metastases (presence/absence) & $16 / 77$ & 0.005 & 2.45 & $1.168-5.172$ & 0.018 \\
\hline Serum AFP $\geq 320$ ng/ml (yes/no) & $47 / 46$ & 0.126 & & & \\
\hline Serum DCP $\geq 1000$ mAU/ml (yes/no) & $49 / 44$ & 0.344 & & & \\
\hline Total bilirubin $\geq 1$ IU/l (yes/no) & $34 / 59$ & 0.653 & & & \\
\hline Serum albumin $\geq 3.5 \mathrm{~g} / \mathrm{dl}$ (yes/no) & $37 / 56$ & 0.042 & 1.15 & $0.560-2.353$ & 0.705 \\
\hline AST > $50 \mathrm{IU} / 1($ yes/no $)$ & $51 / 42$ & 0.424 & & & \\
\hline ALT > 50 IU/1 (yes/no) & $30 / 63$ & 0.671 & & & \\
\hline Serum cholinesterase $\geq 140$ IU/1 (yes/no) & $46 / 47$ & 0.002 & 0.52 & $0.259-1.049$ & 0.068 \\
\hline Prothrombin time $\geq 70 \%$ (yes/no) & $82 / 11$ & 0.192 & & & \\
\hline Serum creatinine $\geq 1$ IU/l (yes/no) & $25 / 68$ & 0.643 & & & \\
\hline Ascites (presence/absence) & $20 / 73$ & 0.001 & 2.07 & $1.180-3.628$ & 0.011 \\
\hline
\end{tabular}

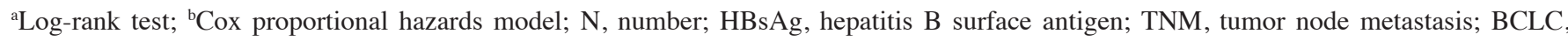
Barcelona Clinic Liver Cancer; AFP, $\alpha$-fetoprotein; DCP, des- $\gamma$-carboxy prothrombin; AST, aspartate aminotransferase; ALT, alanine aminotransferase; HR, hazard ratio; CI, confidence interval.

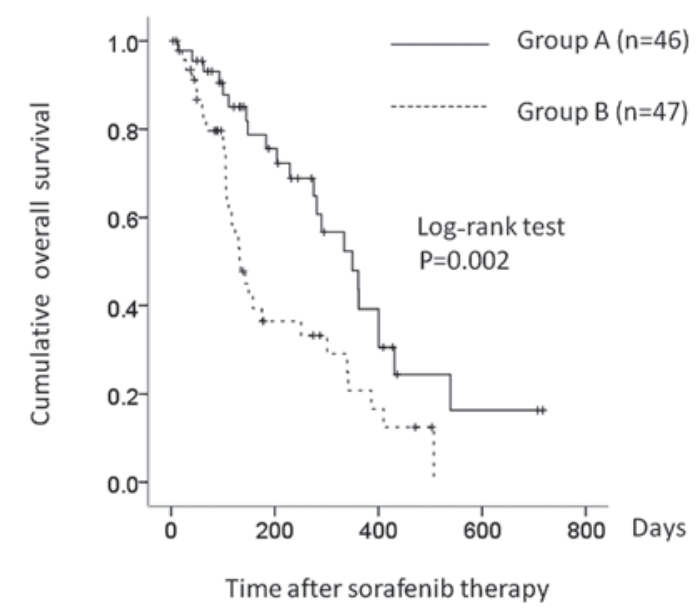

Figure 2. Cumulative overall survival (OS) according to serum cholinesterase (ChE) level. OS was significantly longer in group A patients (serum $\mathrm{ChE} \geq 140 \mathrm{IU} / 1, \mathrm{n}=46$ ) compared to group B patients (serum ChE $<140 \mathrm{IU} / 1$, $\mathrm{n}=47)(\mathrm{P}=0.002)$.

Subgroup analyses in patients with Child-Pugh A. A statistically significant difference was detected between the two groups in terms of baseline Child-Pugh classification. We therefore performed subgroup analyses based on Child-Pugh status. We examined 70 patients with Child-Pugh class A liver function, of whom $41(58.6 \%)$ had higher serum ChE $(\geq 140 \mathrm{IU} / \mathrm{l})$ and 29 (41.4\%) had lower ChE (<140 IU/1).

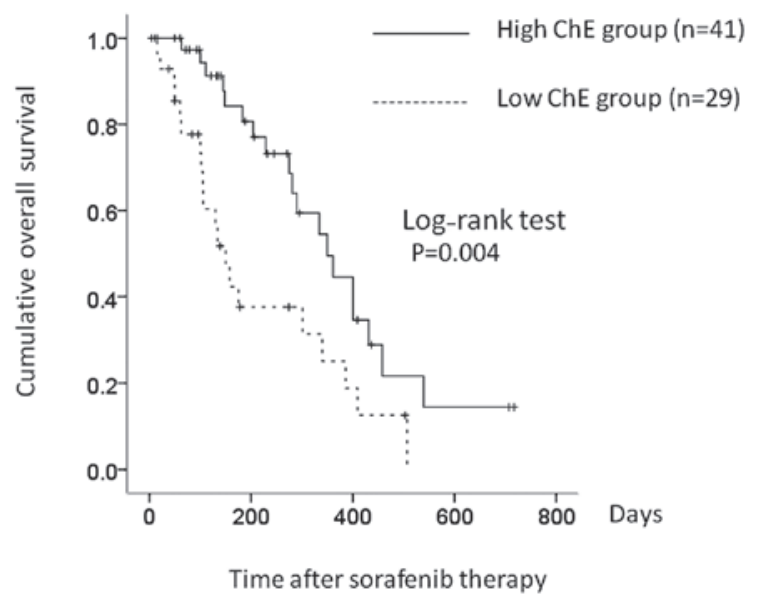

Figure 3. Cumulative overall survival (OS) according to serum cholinesterase (ChE) level in patients with Child-Pugh A $(n=70)$. OS was markedly longer in patients with higher $\mathrm{ChE}$ levels (serum $\mathrm{ChE} \geq 140 \mathrm{IU} / 1, \mathrm{n}=41$ ) compared to those with lower ChE levels (serum ChE <140 IU/1, n=29) $(\mathrm{P}=0.004)$.

Median OS was 350 and 150 days in the higher and lower ChE groups, respectively ( $\mathrm{P}=0.004)$ (Fig. 3). Presence of bone metastases $(\mathrm{P}=0.010)$ and serum $\mathrm{ChE}$ level $(\mathrm{P}=0.004)$ were markedly associated with OS in univariate analyses (Table III), and were significant independent factors linked to OS in Child-Pugh A patients, according to multivariate analyses (Table III). 
Table III. Univariate and multivariate analyses of factors contributing to overall survival in patients with Child-Pugh A ( $\mathrm{n}=70$ ).

\begin{tabular}{|c|c|c|c|c|c|}
\hline \multirow[b]{2}{*}{ Variable } & \multirow[b]{2}{*}{$\mathrm{n}$} & \multirow{2}{*}{$\frac{\text { Univariate analysis }}{\text { P-value }^{\mathrm{a}}}$} & \multicolumn{3}{|c|}{ Multivariate analysis } \\
\hline & & & HR & $95 \% \mathrm{CI}$ & P-value ${ }^{b}$ \\
\hline Age $\geq 70$ years (yes/no) & $35 / 35$ & 0.833 & & & \\
\hline Gender (male/female) & $57 / 13$ & 0.149 & & & \\
\hline HBsAg positive (yes/no) & $14 / 56$ & 0.786 & & & \\
\hline TNM stage, stage III/stage IVA or IVB & $28 / 42$ & 0.132 & & & \\
\hline BCLC stage, $\mathrm{B} / \mathrm{C}$ & $28 / 42$ & 0.163 & & & \\
\hline Portal vein tumor invasion (yes/no) & $12 / 58$ & 0.175 & & & \\
\hline Bone metastases (presence/absence) & $11 / 59$ & 0.010 & 3.367 & $0.121-0.730$ & 0.008 \\
\hline Serum AFP $\geq 320$ ng/ml (yes/no) & $34 / 36$ & 0.283 & & & \\
\hline Serum DCP $\geq 1000$ mAU/ml (yes/no) & $35 / 35$ & 0.526 & & & \\
\hline Total bilirubin $\geq 1$ IU/1 (yes/no) & $22 / 48$ & 0.843 & & & \\
\hline Serum albumin $\geq 3.5 \mathrm{~g} / \mathrm{dl}$ (yes/no) & $34 / 36$ & 0.087 & & & \\
\hline AST $\geq 50$ IU/1 (yes/no) & $36 / 34$ & 0.324 & & & \\
\hline ALT $\geq 50$ IU/l (yes/no) & $22 / 48$ & 0.786 & & & \\
\hline Serum cholinesterase $\geq 140$ IU/1 (yes/no) & $41 / 29$ & 0.004 & 2.612 & $1.174-5.810$ & 0.019 \\
\hline Prothrombin time $\geq 70 \%$ (yes/no) & $42 / 28$ & 0.831 & & & \\
\hline Serum creatinine $\geq 1$ IU/l (yes/no) & $16 / 54$ & 0.702 & & & \\
\hline
\end{tabular}

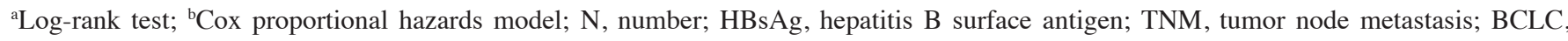
Barcelona Clinic Liver Cancer; AFP, $\alpha$-fetoprotein; DCP, des- $\gamma$-carboxy prothrombin; AST, aspartate aminotransferase; ALT, alanine aminotransferase; HR, hazard ratio; CI, confidence interval.

Predictive factors for severe liver damage. Twenty-two patients $(23.7 \%)$ developed grade 3 or higher liver dysfunction during sorafenib treatment, based on the CTCAE version 4.0, resulting in the interruption or discontinuation of sorafenib therapy. Most instances of severe liver dysfunction occurred within 1 month from the initiation of sorafenib treatment. Only two group A patients (4.3\%) developed liver dysfunction, compared to 20 group B patients (42.6\%).

Results of the univariate analysis showed that TBIL $\geq 1 \mathrm{IU} / 1$ ( $\mathrm{P}=0.041), \mathrm{ALB}<3.5 \mathrm{~g} / \mathrm{dl}(\mathrm{P}=0.015), \mathrm{AST}>50 \mathrm{IU} / \mathrm{l}(\mathrm{P}=0.045)$, $\mathrm{ALT} \geq 50 \mathrm{IU} / 1(\mathrm{P}=0.040)$, serum ChE level $<140 \mathrm{IU} / 1(\mathrm{P}<0.001)$ and the presence of ascites $(\mathrm{P}=0.003)$ were significantly associated with the development of liver dysfunction (Table IV). However, results of the multivariate analysis of these six factors found that only the presence of ascites $(\mathrm{P}=0.030)$ and serum ChE $<140 \mathrm{IU} / 1(\mathrm{P}=0.002)$ were significant independent factors associated with the development of liver dysfunction during sorafenib therapy (Table IV).

Subgroup analyses of severe liver damage in patients with Child-Pugh A. The occurrence of severe liver damage in 70 patients with good liver function (Child-Pugh A) was also examined. Forty-one patients $(58.6 \%)$ had a serum ChE level $\geq 140 \mathrm{IU} / 1$, while the other 29 patients (41.4\%) had a serum ChE level <140 IU/1. Only two patients (4.9\%) with higher $\mathrm{ChE}$ developed severe liver dysfunction, compared to 16 patients (55.2\%) with lower serum ChE.

Univariate analysis results showed TBIL $\geq 1 \mathrm{IU} / 1(\mathrm{P}=0.029)$, AST $\geq 50 \mathrm{IU} / 1(\mathrm{P}=0.007), \mathrm{ALT} \geq 50 \mathrm{IU} / \mathrm{l}(\mathrm{P}=0.029)$ and serum
ChE $(\mathrm{P}<0.001)$ to be significantly associated with the development of severe liver dysfunction (Table V). Multivariate analysis of these four factors showed that pre-treatment serum ChE level was the only independent significant factor associated with the development of severe liver dysfunction $(\mathrm{P}=0.016 ; \mathrm{HR}=0.122 ; 95 \% \mathrm{CI}, 0.022-0.676)$ (Table V).

\section{Discussion}

The positive results of sorafenib therapy identified by the SHARP and Asia-Pacific trials have opened dimensions in the treatment of advanced HCC $(2,3)$. However, in terms of tumor response rate, the efficacy of sorafenib is limited compared to TACE (1). The SHARP trial showed only $2 \%$ of PR in RECIST $(25,26)$, while the Asia-Pacific trial showed only $3 \%$ PR. By contrast, Edeline et al (27) reported that $12 \%$ of HCC patients treated with sorafenib achieved PR using modified RECIST. Abbadessa et al (28) reported that HCC patients benefited from the long-lasting effects of sorafenib. In addition, we have previously treated a patient with advanced HCC with lung metastasis who achieved CR with sorafenib (29). These results suggest that a number of patients may achieve an objective response with sorafenib therapy (27-30). However, characteristics of the patients benefiting from, as well as features associated with sorafenib-resistance have yet to be elucidated.

Llovet et al (7) examined plasma biomarkers as predictors of outcome in HCC patients participating in the SHARP trial and concluded that none of the tested biomarkers predicted a response to sorafenib. Numerous studies have therefore inves- 
Table IV. Univariate and multivariate analyses of factors contributing to the development of liver damage in the cases ( $\mathrm{n}=93$ ).

\begin{tabular}{|c|c|c|c|c|c|}
\hline \multirow[b]{2}{*}{ Variable } & \multirow[b]{2}{*}{$\mathrm{N}$} & \multirow{2}{*}{$\frac{\text { Univariate analysis }^{\text {P-value }}}{\mathrm{a}}$} & \multicolumn{3}{|c|}{ Multivariate analysis } \\
\hline & & & HR & $95 \% \mathrm{CI}$ & P-value ${ }^{b}$ \\
\hline Age $\geq 70$ years (yes/no) & $43 / 50$ & 0.207 & & & \\
\hline Gender (male/female) & $76 / 17$ & 0.631 & & & \\
\hline HBsAg positive (yes/no) & $17 / 76$ & 0.174 & & & \\
\hline TNM stage, stage III/stage IVA or IVB & $37 / 56$ & 0.191 & & & \\
\hline BCLC stage, B/C & $37 / 56$ & 0.086 & & & \\
\hline Portal vein tumor invasion (yes/no) & $18 / 75$ & 0.331 & & & \\
\hline Bone metastases (presence/absence) & $16 / 77$ & 0.558 & & & \\
\hline Serum AFP $\geq 320$ ng/ml (yes/no) & $47 / 46$ & 0.122 & & & \\
\hline Serum DCP $\geq 1000$ mAU/ml (yes/no) & $49 / 44$ & 1.000 & & & \\
\hline Total bilirubin $\geq 1$ IU/1 (yes/no) & $34 / 59$ & 0.041 & 1.881 & $0.564-6.273$ & 0.304 \\
\hline Serum albumin $\geq 3.5 \mathrm{~g} / \mathrm{dl}$ (yes/no) & $37 / 56$ & 0.015 & 0.729 & $0.138-3.840$ & 0.709 \\
\hline AST $\geq 50 \mathrm{IU} / 1$ (yes/no) & $51 / 42$ & 0.045 & 0.824 & $0.179-3.798$ & 0.804 \\
\hline ALT $\geq 50$ IU/1 (yes/no) & $30 / 63$ & 0.04 & 4.269 & $0.933-19.545$ & 0.061 \\
\hline Serum cholinesterase $\geq 140$ IU/1 & $46 / 47$ & $<0.001$ & 0.061 & $0.010-0.373$ & 0.002 \\
\hline Prothrombin time $\geq 70 \%$ (yes $/$ no) & $82 / 11$ & 0.509 & & & \\
\hline Serum creatinine $\geq 1$ IU/l (yes/no) & $25 / 68$ & 0.366 & & & \\
\hline Ascites (presence/absence) & $20 / 73$ & 0.003 & 4.154 & $1.146-15.055$ & 0.030 \\
\hline
\end{tabular}

${ }^{\mathrm{a} F i s h e r ' s ~ e x a c t ~ t e s t ; ~}{ }^{b}$ logistic regression analysis; N, number; HBsAg, hepatitis B surface antigen; TNM, tumor node metastasis; BCLC, Barcelona Clinic Liver Cancer; AFP, $\alpha$-fetoprotein; DCP, des- $\gamma$-carboxy prothrombin; AST, aspartate aminotransferase; ALT, alanine aminotransferase; HR, hazard ratio; CI, confidence interval.

Table V. Univariate and multivariate analyses of factors contributing to liver damage in patients with Child-Pugh A (n=70).

\begin{tabular}{|c|c|c|c|c|c|}
\hline \multirow[b]{2}{*}{ Variable } & \multirow[b]{2}{*}{$\mathrm{N}$} & \multirow{2}{*}{$\frac{\text { Univariate analysis }}{\mathrm{P}-\text { value }^{\mathrm{a}}}$} & \multicolumn{3}{|c|}{ Multivariate analysis } \\
\hline & & & HR & $95 \% \mathrm{CI}$ & P-value ${ }^{b}$ \\
\hline Age $\geq 70$ years $($ yes/no) & $35 / 35$ & 0.500 & & & \\
\hline Gender (male/female) & $57 / 13$ & 0.699 & & & \\
\hline HBsAg positive (yes/no) & $14 / 56$ & 0.143 & & & \\
\hline TNM stage, stage III/stage IVA or IVB & $28 / 42$ & 0.533 & & & \\
\hline BCLC stage, B/C & $28 / 42$ & 0.533 & & & \\
\hline Portal vein tumor invasion (yes/no) & $12 / 58$ & 0.605 & & & \\
\hline Bone metastases (presence/absence) & $11 / 59$ & 0.533 & & & \\
\hline Serum AFP $\geq 320$ ng/ml (yes/no) & $34 / 36$ & 0.077 & & & \\
\hline Serum DCP $\geq 1000$ mAU/ml (yes/no) & $35 / 35$ & 0.752 & & & \\
\hline Total bilirubin $\geq 1$ IU/l (yes/no) & $22 / 48$ & 0.029 & 1.496 & $0.293-7.635$ & 0.628 \\
\hline Serum albumin $\geq 3.5 \mathrm{~g} / \mathrm{dl}$ (yes/no) & $34 / 36$ & 0.190 & & & \\
\hline AST $\geq 50$ IU/1 (yes/no) & $36 / 34$ & 0.007 & 2.330 & $0.268-20.247$ & 0.443 \\
\hline ALT $\geq 50$ IU/1 (yes/no) & $22 / 48$ & 0.029 & 2.104 & $0.374-11.851$ & 0.399 \\
\hline Serum cholinesterase $\geq 140 \mathrm{IU} / 1$ & $41 / 29$ & $<0.001$ & 0.122 & $0.022-0.676$ & 0.016 \\
\hline Prothrombin time $\geq 70 \%$ (yes/no) & $42 / 28$ & 0.708 & & & \\
\hline Serum creatinine $\geq 1 \mathrm{IU} / 1$ (yes/no) & $16 / 54$ & 0.516 & & & \\
\hline
\end{tabular}

${ }^{\mathrm{a}}$ Fisher's exact test; ${ }^{\mathrm{b}}$ logistic regression analysis; N, number; HBsAg, hepatitis B surface antigen; TNM, tumor node metastasis; BCLC, Barcelona Clinic Liver Cancer; AFP, $\alpha$-fetoprotein; DCP, des- $\gamma$-carboxy prothrombin; AST, aspartate aminotransferase; ALT, alanine aminotransferase; HR, hazard ratio; CI, confidence interval. 
tigated biomarkers likely to predict prognosis in HCC patients treated with sorafenib, although no consensus regarding prognostic factors has been reached. Tsukui et al (11) reported that the Child-Pugh classification was a significant prognostic factor, while Morimoto et al (12) reported that the Glasgow prognostic score, Japan integrated staging score and performance status were independently associated with survival. Regarding the clinical course, skin toxicity and reduction of serum $\alpha$-fetoprotein during sorafenib therapy were reported to be associated with OS and time to progression $(31,32)$. However, to the best of our knowledge, no reports have investigated the prognostic value of the serum ChE level.

The presence of ascites and bone metastases, and serum albumin $<3.5 \mathrm{~g} / \mathrm{dl}$ and serum $\mathrm{ChE}$ level $<140 \mathrm{IU} / 1$ were found to be significant indicators of poor OS in the univariate analysis. TNM and BCLC stage did not contribute to OS. These findings are partially in agreement with those of Tsukui et al (11), who reported that background liver disease-derived factors, rather than tumor-derived factors, were correlated with prognosis in advanced HCC patients treated with sorafenib. By contrast, results of the multivariate analysis showed that the presence of bone metastases was a significant adverse prognostic factor in the analyzed patients as well as in Child-Pugh A patients. Advanced HCC patients with bone metastasis frequently present with severe pain and other symptoms associated with poor quality of life (33), thus these factors are likely to be associated with poor prognosis.

In general, patients with pretreatment liver function damage, such as Child-Pugh B, elevated AST or ALT, hypoalbuminemia and the presence of ascites are considered to be intolerant to sorafenib therapy (1-5). Results of the multivariate analysis demonstrated serum ChE level to be the strongest predictive factor for severe liver dysfunction. Under conditions of poor hepatic functional reserve, reflected by lower serum ChE levels, hepatocytes may easily be damaged by systemic chemotherapy, leading to severe liver damage. Our findings suggest that the serum ChE level, as well as the above-mentioned factors, are important predictors correlated with the development of severe liver dysfunction. Consequently, clinicians should take serum ChE levels into consideration prior to initiation of sorafenib therapy.

The present study found that pretreatment serum $\mathrm{ChE}$ $<140$ IU/l was a significant poor prognostic factor in the multivariate analysis in the subgroup of patients with good liver function of Child-Pugh class A. Moreover, patients with pretreatment serum $\mathrm{ChE}<140 \mathrm{IU} / 1$ were more likely to develop severe liver dysfunction during sorafenib treatment compared to those with pretreatment serum $\mathrm{ChE}>140$ IU/l. These findings suggest that even patients with good pretreatment liver function of Child-Pugh class A should be treated with sorafenib with caution if they have low serum ChE levels, and a favorable clinical outcome in these patients is less likely as a result of the high frequency of discontinuation of sorafenib therapy.

There were several limitations to the present study. First, this was a retrospective, single-center study. Second, the number of patients analyzed was relatively small. Third, the initial sorafenib dose varied in individual patients, which could have led to bias. Fourth, nine patients whose pretreatment ChE levels were not tested were excluded from the study, also potentially leading to bias. A larger prospective study is therefore needed to clarify the prognostic factors in advanced HCC patients treated with sorafenib. Nevertheless, the findings of this study have demonstrated that lower pretreatment serum ChE levels were a significant risk factor for poor prognosis and liver dysfunction, even in patients with pretreatment Child-Pugh A liver function, suggesting that patients with lower serum ChE levels should be treated with caution.

In conclusion, serum $\mathrm{ChE}$ level may be a reliable prognostic marker for the treatment of patients with advanced HCC in the sorafenib era. Clinicians should therefore be aware of serum ChE levels, as well as various other clinical findings, prior to initiation of sorafenib therapy.

\section{Acknowledgements}

The authors would like to thank Haruko Takada for the data collection.

\section{References}

1. Nishikawa H, Osaki Y, Kita R and Kimura T: Hepatic arterial infusion chemotherapy for advanced hepatocellular carcinoma in Japan. Cancers 4: 165-183, 2012.

2. Llovet JM, Ricci S, Mazzaferro V, Hilgard P, Gane E, Blanc JF de Oliveira AC, Santoro A, Raoul JL, Forner A, Schwartz M, Porta C, Zeuzem S, Bolondi L, Greten TF, Galle PR, Seitz JF, Borbath I, Häussinger D, Giannaris T, Shan M, Moscovici M, Voliotis D and Bruix J: SHARP Investigators Study Group: Sorafenib in advanced hepatocellular carcinoma. N Engl J Med 359: 378-390, 2008.

3. Abou-Alfa GK, Schwartz L, Ricci S, Amadori D, Santoro A, Figer A, De Greve J, Douillard JY, Lathia C, Schwartz B, Taylor I, Moscovici M and Saltz LB: Phase II study of sorafenib in patients with advanced hepatocellular carcinoma. J Clin Oncol 24: 4293-4300, 2006.

4. Cheng AL, Kang YK, Chen Z, Tsao CJ, Qin S, Kim JS, Luo R, Feng J, Ye S, Yang TS, Xu J, Sun Y, Liang H, Liu J, Wang J, Tak WY, Pan H, Burock K, Zou J, Voliotis D and Guan Z: Efficacy and safety of sorafenib in patients in the Asia-Pacific region with advanced hepatocellular carcinoma: a phase III randomised, double-blind, placebo-controlled trial. Lancet Oncol 10: 25-34, 2009.

5. Wilhelm SM, Carter C, Tang L, Wilkie D, McNabola A, Rong H, Chen C, Zhang X, Vincent P, McHugh M, Cao Y, Shujath J, Gawlak S, Eveleigh D, Rowley B, Liu L, Adnane L, Lynch M, Auclair D, Taylor I, Gedrich R, Voznesensky A, Riedl B, Post LE, Bollag G and Trail PA: BAY 43-9006 exhibits broad spectrum oral antitumor activity and targets the RAF/MEK/ ERK pathway and receptor tyrosine kinases involved in tumor progression and angiogenesis. Cancer Res 64: 7099-7109, 2004.

6. Baek KK, Kim JH, Uhm JE, Park SH, Lee J, Parl JO, Park YS, Kang WK and Lim HY: Prognostic factors in patients with advanced hepatocellular carcinoma treated with sorafenib: a retrospective comparison with previously known prognostic models. Oncology 80: 167-174, 2011.

7. Llovet JM, Peña CE, Lathia CD, Shan M, Meinhardt G and Bruix J; SHARP Investigators Study Group: Plasma biomarkers as predictors of outcome in patients with advanced hepatocellular carcinoma. Clin Cancer Res 18: 2290-2300, 2012.

8. Raoul JL, Bruix J, Greten TF, Sherman M, Mazzaferro V, Hilgard P, Scherubl H, Scheulen ME, Germanidis G, Dominguez S, Ricci S, Nadel A, Moscovici M, Voliotis D and Llovet JM: Relationship between baseline hepatic status and outcome, and effect of sorafenib on liver function: SHARP trial subanalyses. J Hepatol 56: 1080-1088, 2012.

9. Cheng AL, Guan Z, Chen Z, Tsao CJ, Qin S, Kim JS, Yang TS, Tak WY, Pan H, Yu S, Xu J, Fang F, Zou J, Lentini G, Voliotis D and Kang YK: Efficacy and safety of sorafenib in patients with advanced hepatocellular carcinoma according to baseline status: subset analyses of the phase III sorafenib Asia-Pacific trial. Eur J Cancer 48: 1456-1465, 2012. 
10. Ezzoukhry Z, Louandre C, Trécherel E, Godin C, Chauffert B, Dupont $\mathrm{S}$, Diouf $\mathrm{M}$, Barbare JC, Mazière JC and Galmiche A: EGFR activation is a potential determinant of primary resistance of hepatocellular carcinoma cells to sorafenib. Int J Cancer: doi: 10.1002/ijc. 27604 .

11. Tsukui Y, Mochizuki H, Hoshino Y, Kawakami S, Kuno T, Fukasawa Y, Iwamoto F, Hirose S, Yoshida T, Hosoda K, Suzuki Y, Hosoda K, Kojima Y, Hirose Y, Shindou K, Matsuda M, Yagawa S, Tawara A, Kobayashi M, Konishi T, Yamazaki T, Takahashi S, Fujii $\mathrm{H}$, Enomoto $\mathrm{N}$ and Omata M: Factors contributing to the overall survival in patients with hepatocellular carcinoma treated by sorafenib. Hepatogastroenterology: doi: 10.5754/hge12059.

12. Morimoto M, Numata K, Moriya S, Kondo M, Nozaki A, Morioka Y, Maeda S and Tanaka K: Inflammation-based prognostic score for hepatocellular carcinoma patients on sorafenib treatment. Anticancer Res 32: 619-623, 2012.

13. Mohri Y, Tanaka K, Ohi M, Yokoe T, Miki C and Kusunoki M: Prognostic significance of host- and tumor-related factors in patients with gastric cancer. World J Surg 34: 285-290, 2010

14. Battisti V, Bagatini MD, Maders LD, Chiesa J, Santos KF Gonçalves JF, Abdalla FH, Battisti IE, Schetinger MR and Morsch VM: Cholinesterase activities and biochemical determinations in patients with prostate cancer: influence of Gleason score, treatment and bone metastasis. Biomed Pharmacother 66: 249-255, 2012

15. Mitsunaga S, Kinoshita T, Hasebe T, Nakagohri T, Konishi M, Takahashi S, Gotohda N and Ochiai A: Low serum level of cholinesterase at recurrence of pancreatic cancer is a poor prognostic factor and relates to systemic disorder and nerve plexus invasion. Pancreas 36: 241-248, 2008.

16. Morera Ocón FJ, Ripoll Orts F, García-Granero Ximénez M, Pastor MJ and Bernal Sprekelsen JC: Decrease of serum cholinesterase in colorectal cancer. Med Clin (Barc) 129: 729-730, 2007 (In Spanish)

17. Chougule A, Hussain S and Agarwal DP: Prognostic and diagnostic value of serum pseudocholinesterase, serum aspartate transaminase, and serum alinine transaminase in malignancies treated by radiotherapy. J Cancer Res Ther 4: 21-25, 2008.

18. Hamamoto $\mathrm{Y}$, Niino $\mathrm{K}$, Ishiyama $\mathrm{H}$ and Hosoya $\mathrm{T}$ : Impact of pretreatment cholinesterase level on survival of inoperable intrahepatic or hepatic-hilar carcinomas treated with three-dimensional conformal radiotherapy. Radiat Med 22: 316-323, 2004.

19. Nishikawa H, Osaki Y, Inuzuka T, Takeda H, Nakajima J, Matsuda F, Henmi S, Sakamoto A, Ishikawa T, Saito S, Kita R and Kimura T: Branched-chain amino acid treatment before transcatheter arterial chemoembolization for hepatocellular carcinoma. World J Gastroenterol 18: 1379-1384, 2012.

20. Kaibori M, Matsui K, Saito T and Kamiyama Y: Risk factors for early death due to recurrence after resection of large hepatocellular carcinomas. Hepatogastroenterology 55: 2151-2156, 2008.

21. Weismüller TJ, Prokein J, Becker T, Barg-Hock H, Klempnauer J, Manns MP and Strassburg CP: Prediction of survival after liver transplantation by pre-transplant parameters. Scand J Gastroenterol 43: 736-746, 2008.
22. Motta M, Giugno I, Ruello P, Pistone G, Di Fazio I and Malaguarnera M: Lipoprotein (a) behaviour in patients with hepatocellular carcinoma. Minerva Med 92: 301-305, 2001.

23. Fernández Prieto RM, Ramallo Bravo A, Carmona Carmona G and Carrasco Jiménez MS: Update on the current role of plasma cholinesterase. Rev Esp Anestesiol Reanim 58: 508-516, 2011 (In Spanish).

24. Lencioni R and Llovet JM: Modified RECIST (mRECIST) assessment for hepatocellular carcinoma. Seminars in Liver Dis 30: 52-60, 2010.

25. Therasse P, Arbuck SG, Eisenhauer EA, Wanders J, Kaplan RS, Rubinstein L, Verweij J, Van Glabbeke M, van Oosterom AT, Christian MC and Gwyther SG: New guidelines to evaluate the response to treatment in solid tumors. European Organization for Research and Treatment of Cancer, National Cancer Institute of the United States, National Cancer Institute of Canada. J Natl Cancer Inst 92: 205-216, 2000.

26. Eisenhauer EA, Therasse P, Bogaerts J, Schwartz LH, Sargent D, Ford R, Dancey J, Arbuck S, Gwyther S, Mooney M, Rubinstein L, Shankar L, Dodd L, Kaplan R, Lacombe D and Verweij J: New response evaluation criteria in solid tumors: revised RECIST guideline (ver.1.1). Eur J Cancer 45: 228-247, 2009.

27. Edeline J, Boucher E, Rolland Y, Vauléon E, Pracht M, Perrin C, Le Roux C and Raoul JL: Comparison of tumor response by Response Evaluation Criteria in Solid Tumors (RECIST) and modified RECIST in patients treated with sorafenib for hepatocellular carcinoma. Cancer 118: 147-156, 2012.

28. Abbadessa G, Rimassa L, Pressiani T, Carrillo-Infante C, Cucchi E and Santoro A: Optimized management of advanced hepatocellular carcinoma: four long-lasting responses to sorafenib. World J Gastroenterol 17: 2450-2453, 2011.

29. Inuzuka T, Nishikawa H, Sekikawa A, Takeda H, Henmi S, Sakamoto A, Saito S, Kita R, Kimura T, Osaki Y and Kudo M: Complete response of advanced hepatocellular carcinoma with multiple lung metastases treated with sorafenib: case report. Oncology 81: 152-157, 2011.

30. Sacco R, Bargellini I, Gianluigi G, Bertini M, Bozzi E, Altomare E, Battaglia V, Romano A, Bertoni M, Capria A, Bresci $\mathrm{G}$ and Bartolozzi C: Complete response for advanced liver cancer during sorafenib therapy: case report. BMC Gastroenterol 11: 4, 2011

31. Shao YY, Lin ZZ, Hsu C, Shen YC, Hsu CH and Cheng AL: Early alpha-fetoprotein response predicts treatment efficacy of antiangiogenic systemic therapy in patients with advanced hepatocellular carcinoma. Cancer 116: 4590-4596, 2010.

32. Vincenzi B, Santini D, Russo A, Addeo R, Giuliani F, Montella L, Rizzo S, Venditti O, Frezza AM, Caraglia M, Colucci G, Del Prete S and Tonini G: Early skin toxicity as a predictive factor for tumor control in hepatocellular carcinoma patients treated with sorafenib. Oncologist 15: 85-92, 2010

33. Xiang ZL, Zeng ZC, Tang ZY, Fan J, He J, Zeng HY and Zhu XD: Potential prognostic biomarkers for bone metastasis from hepatocellular carcinoma. Oncologist 16: 1028-1039, 2011. 